address and date of birth should be enclosed in a sealed covering letter attached to the essay and addressed to the Deputy Secretary of the British Association.

\section{The Mathematics of Control Systems}

THE second residential conference of the Institute of Mathematics and its Applications on "The Mathematics of Control Systems" will be held at Sunderland T'echnical College during April 3-6. The following lectures have also been arranged: "Non-linear Hydrodynamic Stability" by Prof. P. H. Roberts (Constantine Technical College, Middlesbrough, on February 21); "Reciprocity Theorems in Applied Mathematies" by Prof. G. J. Kynch (Birmingham College of Advanced Technology, on February 22); "Application of Mathematics to Problems arising in the Electrical Manufacturing Industry" by Mr. N. Kerruish (University of Leeds, on February 22); "Mathematics applied to the Large-scale Dynamics of the Atmosphere" by Mr. J. S. Sawyer (University of Strathclyde, on February 24); "Mathematies in Electrical Engineering" by Mr. N. Kerruish (Birmingham College of Advanced Technology, on March 2). Further information can be obtained from the Institute of Mathematics and its Applications, Maitland House, Warrior Square, Southendon-Sea, Essex.

\section{University and College News:}

Belfast

Dr. D. J. Bradeey, reader in physics at Royal Holloway College, London, has been appointed to the chair of physics. The following appointments have also been made: Readerships: Dr. R. Common (geography); Dr. M. F. Grundon (organic chemistry); Dr. A. P. Roberts (engineering mathematics); Dr. F. J. Smith (applied mathematics); Senior Lectureships: Dr. R. M. Hobson (physics); Dr. D. McCloy (mechanical engineering); Mr. N. Stephens (geography); Mr. B. C. S. Wilson (archaeology).

\section{The College of Advanced Technology, Birmingham}

DR. F. M. PAGE has been appointed professor of chemistry.

London

Dr. B. R. Coles, at present reader in physics at the Imperial College of Science and Technology, has been appointed to the chair of solid-state physics tenable at that College, from October 1.

\section{Southampton}

Dr. I. R. Beattie has been appointed to the chair of inorganic chemistry. Dr. J. M. Nightingale has been appointed to the chair of control engineering. Mr. R. A. Farrar has been appointed lecturer in mechanical engineering.

\section{Announcements}

Dr. M. A. Tuve, director of the Department of Terrestrial Magnetism of the Carnegie Institution of Washington, has been appointed home secretary of the United States National Academy of Sciences, in succession to the late Dr. H. L. Dryden.

DR. L. Schiff, executive head of the Department of Physics at Stanford University, has been awarded the 1966 Oersted Medal by the American Association of Physics Teachers, for notable contributions to the teaching of physics.

THE address of the Plant Variety Rights Office is now Murray House, Vandon Street, London, S.W.1.

THE title of the Fruit and Vegetable Canning and Quick Freezing Research Association is now the Fruit and Vegetable Preservation Research Association.

A symposium on "The Place of the Chemist in Industry", organized by the Royal Institute of Chemistry, will be held at the Oxford College of Technology on March 3. Further information can be obtained from Mr. W. Sabel, Oxford College of Technology, Headington Road, Oxford.

A symposium on "Chemistry and Rheology of Water Soluble Gums and Colloids", arranged jointly by the Colloid and Surface Chemistry Group of the Society of Chemical Industry and the British Society of Rheology, will be held at the School of Pharmacy, University of London, on March 28. Further information can be obtained from Mr. B. Warburton, Department of Pharma. ceutics, School of Pharmacy, 29-39 Brunswick Square, London, W.C.1.

A workING conference on inter-personal and intergroup relations entitled "Learning and Leadership", arranged by the Department of Adult Education of the University of Leicester in collaboration with the Tavistock Institute of Human Relations, will be held in the University of Leicester during March 25-April 7. Further information can be obtained from Miss D. J. Bostock, Tavistock Institute of Human Relations, 3 Devonshire Street, London, W.l.

CoRrigendum. In the article entitled "Isotopic Ages of Minerals from the Pre-Cambrian Complex of the Malverns", by Dr. R. St. J. Lambert and D. C. Rex (Nature, 209, 605; 1966), the second sentence of paragraph three, p. 606, line 14, should read "A Callavia fauna...".

\title{
THE NIGHT SKY IN MARCH
}

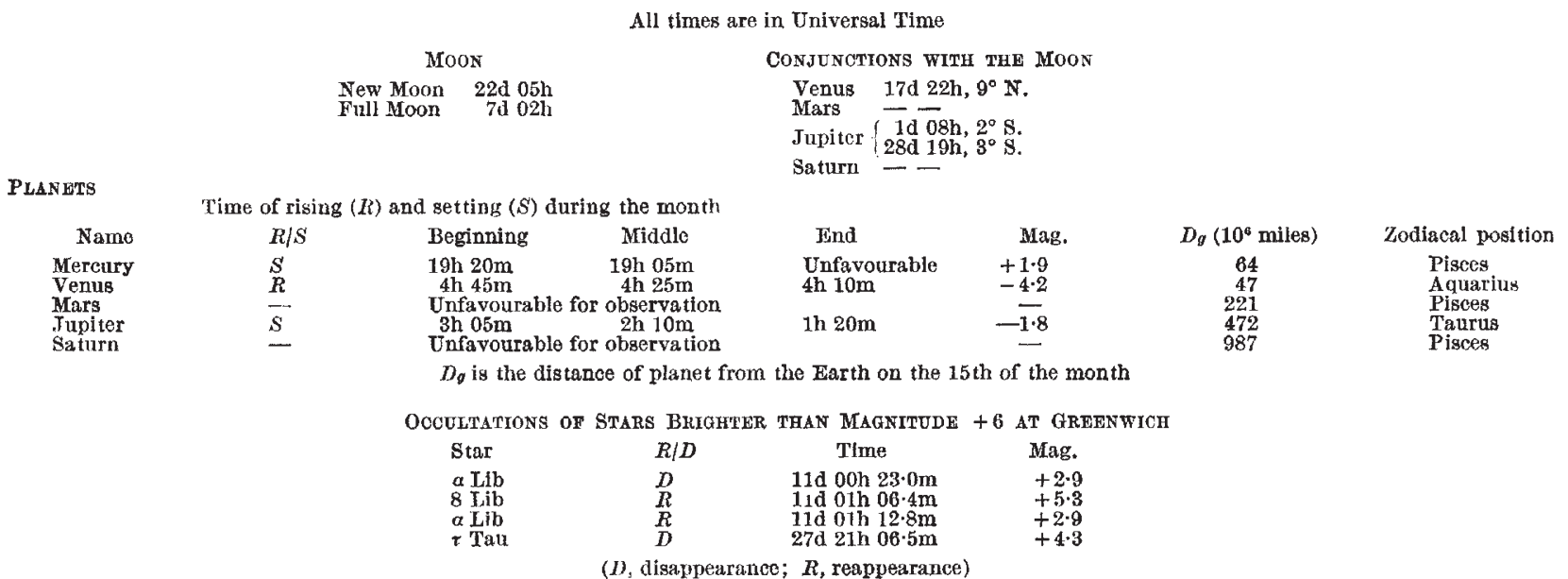

Other Phanomena

( $D$, disappearance; $R$, reappearance)

$7 \mathrm{~d} 02 \mathrm{~h}$, Uranus $4^{\circ} \mathrm{s}$, of Moon 